\title{
LITERATURE REVIEW \\ New records and additions to the Chilean bryophyte flora
}

\author{
Jorge Cuvertino ${ }^{1}$, Víctor Ardiles ${ }^{2}$, Felipe Osorio ${ }^{3}$, and Ximena Romero ${ }^{4}$ \\ ${ }^{1}$ Dirección de Investigación y Postgrado. Facultad de Agronomía, Pontificia Universidad Católica de Chile. \\ Vicuña Mackenna 4860, Macul, Santiago, Chile. \\ ${ }^{2}$ Área Botánica. Museo Nacional de Historia Natural. Parque Quinta Normal s/n. Santiago, Chile. \\ ${ }^{3}$ Instituto de Ciencias Ambientales y Evolutivas, Facultad de Ciencias, Universidad Austral de Chile. Casilla \\ 567, Valdivia, Chile. \\ ${ }^{4}$ Escuela de Ecoturismo, Facultad de Recursos Naturales, Universidad Nacional Andrés Bello. República \\ 237, Santiago, Chile.
}

\begin{abstract}
J. Cuvertino, V. Ardiles, F. Osorio, and X. Romero. 2012. New records and additions to the Chilean bryophyte flora. Cien. Inv. Agr. 39(2): 245-254. Bryological knowledge in Chile is incomplete. With the aim of making a contribution to a better understanding of the geographic distribution of these species and encourage bryological studies and the conservation of these plants in the country, the results of floristic investigations are presented. Nineteen national, regional and provincial records for 17 species of bryophytes are provided based on revision of specimens and overlooked literature. The ranges of six species are expanded. In addition, the site of the original collection of one taxon (Barbula austrogracilis Dus.) is corrected, and a second specimen is verified.
\end{abstract}

Key words: bryophytes, Chile, Chilean flora.

\section{Introduction}

Bryophytes have an interesting floristic value in southern Chile that it is often overlooked due to a historical bias toward vertebrates and vascular plants in the Northern Hemisphere (Rozzi et $a l ., 2008)$. For instance, 25 endemic genera of liverworts are present in the temperate terrestrial ecosystems of Chile and Argentina, representing one of the World's richest biodiversity areas (Asakawa et al., 2009). Furthermore, Hässel de Menéndez (1998) reported an estimated

Received September 7, 2011. Accepted April 24, 2012.

Corresponding author: sjorgeandres@uc.cl endemism as high as $60 \%$ for the liverwort flora shared by Chile and Argentina. Nevertheless, central Chile also displays a variety of taxa that are narrowly distributed within a region highly affected by the development of agro-industrial activities and the expansion of urban areas. This part of the country hosts a group of endemic taxa of unquestionable conservation concern to be investigated. As part of new efforts to investigate this region, Larraín et al. (2009) proposed that the endemic species Costesia macrocarpa (Schimper) Cuvertino, Miserere and Buffa should be categorized as vulnerable in the IUCN Red List of Threatened Species. The "fueguian" moss Skottsbergia paradoxa 
Card. is already listed in the IUCN Red List (IUCN, 2008).

To contribute to our knowledge of this area, this article focuses on the bryophyte flora of southern and central Chile. We present a list of 18 taxa, including some taxonomic, distributional and ecological information, and a map (Figure 1) displaying the new administrative regions of Chile (IGMCH, 2002) together with the new records and additions registered.

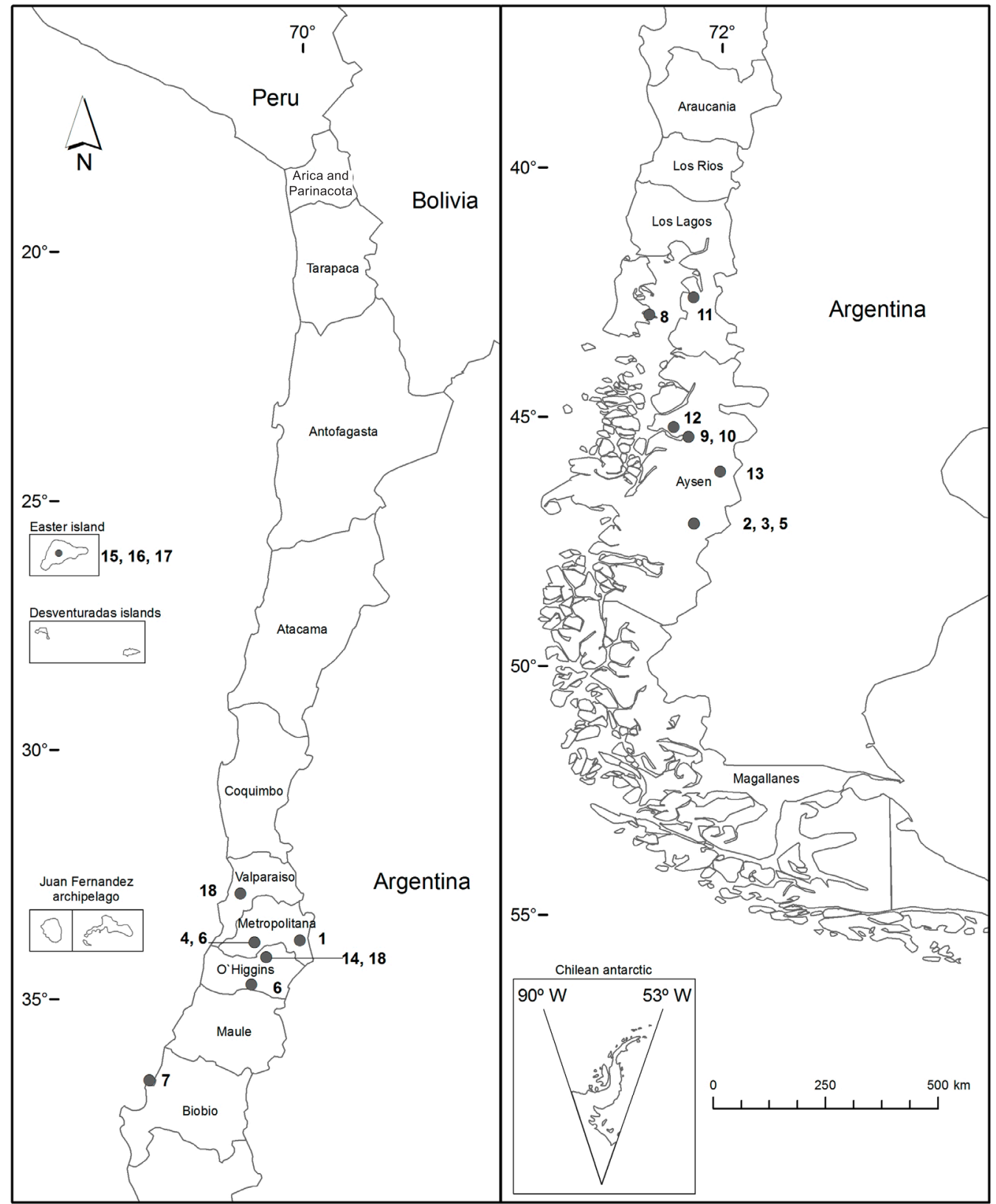

Figure 1. Map of the new political regions of Chile together with the records. 


\section{Materials and methods}

The new records (13 of the 19) and range extensions presented herein are based on recent bryophyte specimens gathered during the last ten years by the authors and their collaborators in eight localities of southern and central Chile: the Natural Monument El Morado, Metropolitan Region; the Altos de Cantillana Reserve, Metropolitan Region; Chimbarongo City, Libertador Bernardo O’Higgins Region; Tranqui Island, Archipelago of Chiloé, Los Lagos Region; Pumalín Park, Los Lagos Region; Tamango National Reserve, Aysén Region; Puerto Aysén, Aysén Region; the Cuervo River, Aysén Region; and Cerro Castillo Mount, Aysén Region.

The rest of the records were obtained from revisions of herbarium specimens (Muséum National d'Histoire Naturelle, PC, Missouri Botanical Garden, $\mathrm{MO}$ ) and bibliographic research.

The specimens were carefully studied by comparing their morphological features to the literature and/ or types and non-types. To establish distribution patterns, we referred to Hässel de Menéndez and Rubies (2009), Müller (2009) and Tropicos ${ }^{\circledR}$ (2011) (an online database) and to specimens kept at SGO (Museo Nacional de Historia Natural).

The specimens are maintained in the following herbaria: SGO, PC and MO.

\section{Results and discussion}

From recently collected specimens, we report 14 new records. These records were distributed as follows: six from the Aysén Region, two from the Metropolitan Region, one each from the Libertador Bernardo O’Higgins, Biobío, Los Lagos Regions, and one each from the San José de Maipo, Palena, and Capitán Prat Provinces. Six records correspond to southern (3) and northern (3) range extensions.
Five records are based on revision of the literature: Syntrichia flagellaris in the O'Higgins Region and the Province of Quillota (Thèriot, 1917; Tixier, 1988) and Sematophyllum contiguum, Chiloscyphus trigonifolius and Lejeunea micholitzii from Easter Island were overlooked in the elaboration of checklists of Chilean mosses and liverworts (He, 1998; Müller, 2009; Hässel de Menéndez and Rubies, 2009). In addition, the site of the original collection of one taxon (Barbula austrogracilis Dus.) was corrected to the Province of Cachapoal, and a second specimen was verified for this area.

Annotated list of species and specimens: recent specimens

1. Anastrophyllum involutifolium (Mont. ex Gottsche, Lindenb. and Nees) Steph. (SGO 157516), Province of San José de Maipo, Metropolitan Region: Monumento Nacional El Morado, Víctor Ardiles y Christian Varas, 01.11.2005, 33 ${ }^{\circ} 49^{\prime}$ $21,8^{\prime}$ 'S - 70 $03^{\circ} 50,4^{\prime \prime} \mathrm{W}, 1800$ masl. New for the Metropolitan Region. Northern extension of its distribution range in Chile.

The specimen was found growing in wet soil, near a stream, between rocks and cushions of Dicranum sp. Distinctive characters of the species include retuse and dark-reddish leaves with margins that are often incurved to involuted and without amphigastria. Its global distribution includes Argentina, South Georgia and the South Sandwich Islands (Matteri, 1985). In Chile, this species has been recorded in the following areas in the Magallanes Region: Desolación Island, Narrow Harbour, Borja Bay, Brunswick Peninsula, End Sands, Basket Island, Toro Harbour, Cove Without Exit, Piazzi Island, Rennell Island, Vidal Gormaz Island, Virtues Island, Diego de Almagro Island, and Harbour Cutter (SGO 120630). The type corresponds to a specimen recorded in San Nicolas Bay. It has also been recorded in the regions of Los Ríos (Valdivia), Valparaíso, and Juan Fernández Island, in a Nothofagus Forest 
in Osorno Volcano and in the Los Lagos Region (SGO 106811).

2. Barbilophozia hatcheri (A. Evans) Loeske. (SGO 159658) Province of Capitán Prat, Aysén Region: Tamango Reserve, on the way to the summit of Cerro Tamango, Donna Maden, 02.2001, $47^{\circ} 08^{\prime} 44,55^{\prime}$ ' S - 72 $34^{\prime} 17,79^{\prime \prime}$ W. New for the Region. Northern extension of its distribution range in Chile.

This species was collected at 1,200 masl growing intermixed with Brachythecium subpilosum (Hook. f. and Wilson) A. Jaeger. on the ground within the timberline of a Nothofagus pumilio (Poepp. \& Endl.) Krasser forest. A complete description, illustration and distribution map of the species can be found in Bednarek-Ochyra et al. (2000). It is considered a Bipolar, Arctic-alpine species and is found in North America, Europe and extending to Japan. In the Southern Hemisphere, it has been registered at the southern tip of South America, in the Malvinas Islands (Falkland Islands) and South Georgia Islands and on the Antarctic Peninsula (Bednarek-Ochyra et al., 2000). In Chile, the species has been registered only in the Magallanes Region.

3. Brachythecium subpilosum (Hook. f. and Wilson) A. Jaeger. (SGO 159658), Province of Capitán Prat, Aysén Region: Tamango Reserve, on the way to the summit of Cerro Tamango, Donna Maden, $02.2001,47^{\circ} 08^{\prime} 44,55^{\prime \prime} \mathrm{S}-72^{\circ}$ 34' 17,79" W. New for the Province.

This species was collected at 1200 masl growing intermixed with Barbilophozia hatchery (A. Evans) Loeske, as above. The species grows in a variety of habitats, including the fissures of rocks, on the ground and on pebbled slopes (Putzke and Pereira, 2001). Distinctive characters of the species include its triangular to ovate-cordate shortly decurrent leaves, with a plane or slightly recurved margin in the basal third of the lamina (Putzke and Pereira, 2001; Mitten, 1869). It is known from Argentina, the Malvinas Islands
(Falklands Islands), Kerguelen Is., Marion Is., the South Shetland Islands, South Georgia and the Antarctic Peninsula. It has been registered in Chile from the Provinces of Nuble to Antartica Chilena.

4. Costesia macrocarpa (Schimp.) Cuvertino, Miserere and Buffa. (SGO 159655), Province of El Maipo, Metropolitan Region: Reserva Altos de Cantillana, Sector Aculeo, Portezuelo Delgado, sclerophyllous scrub floor, 836 masl, Ximena Romero, 03.09.2010, 0317734 E - 6250114 N. New for the Province.

The specimen was collected growing on bare soil and soil among grasses, sometimes related to outcrops on relatively exposed slopes in pristine areas where sclerophyllous forest and scrub dominate. Distinctive characters of the species include perigonial paraphyses filiform without inflated terminal cells, large subglobose capsules, stomata enclosed by two guard cells and a rugose-spongiose exothecium when dry. Costesia is a monospecific endemic genus from central Chile (Larraín et al., 2009). The species has been registered from the Coquimbo Region to the Libertador Bernardo O'Higgins Region.

5. Distichium capillaceum (Hedw.) Bruch and Schimp. (SGO 149227), Province of Capitán Prat, Aysén Region: Tamango Reserve, on the way to the summit of Cerro Tamango, Tim Bradburn, 16.02.2001, $47^{\circ} 08^{\prime} 44,55^{\prime}$ ' S - 72 34' 17,79” W. New for the Region.

Specimens were found growing among stones at 1540 masl intermixed with Bartramia ithyphylla subsp. patens (Brid.) Fransén, Brachythecium subpilosum (Hook.f. \& Wilson) A. Jaeger (a new record for the Province), and Cladonia sp. The species of the genus appear similar to Ditrichum but differ from them in the distichous arrangement of the leaves. This species is widely distributed in the Northern and Southern Hemispheres. It has been registered in Chile 
in the Maule Region, Los Lagos Region and Magallanes Region.

\section{Fissidens berterii (Mont.) Müll. Hal. a) (SGO 159653), Province of El Maipo, Metropolitan Re- gion: Reserva Altos de Cantillana, Sector Aculeo, Quebrada Las Pataguas, on submerged rock at 701 masl, Ximena Romero, 15.06.2010, 0318699 E - 6249985 N. b) (SGO 159657) Province of Col- chagua, Libertador Bernardo O'Higgins Region: Chimbarongo, main entrance of the village, on concrete in an irrigation canal, Jorge Cuvertino, 08.06.2010, 34 42' 53" S - 71 01' 54” W. New for both regions.}

This species is one of the three aquatic Fissidens found in Chile growing submerged in slowly to rapidly flowing waters (Müller and Pursell, 2003). It was first described by Montagne as Octodiceras berteroi based on a specimen collected by $\mathrm{C}$. Bertero in Quillota. It is distinguished by its lateral sporophytes and by the costa ending 15 or more cells below the leaf apex. It is known from Argentina, Bolivia, Peru, Uruguay, Brazil and New Zealand. In Chile, it has been registered in the Provinces of Aconcagua, Quillota and Valparaíso in the Valparaíso Region and in the Province of Chiloé in the Los Lagos Region.

7. Funaria costesii Thér. (MO-2100664), Province of Concepción, Biobío Region: Funaria commixta Thér. In rocky soil on a cliff beside the ocean. Tumbes Peninsula, $36^{\circ} 38^{\prime}$ S - $73^{\circ} 05^{\prime}$ W. Alt. ca. 0 to $58 \mathrm{~m}$, September 16, 2001, R.R. Ireland and G. Bellolio, № 31631. New for the Region. Southern extension of the distribution range.

The material was erroneously identified as Funaria commixta. The specimen, compared to the syn-types from Los Perales and Playa Ancha (Valparaíso Region), shows slight differences in leaf morphology, possibly due to the different environmental conditions at these sites. The costa frequently appears more reddish than in the syn-types in which it is generally yellowish and concolorous. The leaf margins, which exhibit blunty teeth in the syn-types, are less pronounced in the specimen from Bio-Bio. Description and illustration in Thériot (1921). The species has been previously reported from the Coquimbo, Valparaíso and Metropolitan Regions (He, 1998; Müller, 2009) and is probably endemic to central Chile.

\section{Haplomitrium gibbsiae (Steph.) Schust. (SGO} 157518), Province of Chiloé, Los Lagos Region: Queilen Commune. Archipelago of Chiloé, Tranqui Island, Victor Ardiles and Pablo Sandoval, 07.02.2009, $42^{\circ} 57^{\prime} 05,08^{\prime \prime} \mathrm{S}-73^{\circ} 27^{\prime} 53,75^{\prime}$ " W, 47 masl. New for the Region and new for the Archipelago of Chiloé. Northern extension of its distribution range.

The plants were found growing on wet soil among Isotachis grossidens Steph. Distinctive characters of the species include its whitish, fleshy and creeping talli, with few leaves, which are bright green, ovate to orbiculate, and transversally inserted. Its global distribution comprises New Zealand, Argentina and Chile (Hässel de Menéndez and Solari, 1975). It has been recorded in Chile only in the Magallanes Region, within the following areas: Borja Bay, Piazzi Island, Rennell Islands, Vidal Gormaz Island, Clarence Island and Ancón Sin Salida. There are studies currently being performed on the liverwort flora of the Archipelago of Chiloé and mainly focused on the Guaquipillan Archipelago, Esmeralda Archipelago and Piuché mountain range, but they have not recorded this species. Stech and Frey (2004) recorded a related species, Haplomitrium chilensis, in Hornopirén National Park in the Los Lagos Region. H. gibbsiae is a new addition to the local bryophyte flora.

9. Juratzkaea seminervis (Kunze ex Schwägr.) Lorentz subsp. seminervis (SGO 160471), Province of Aysén, Aysén Region: Municipality of Puerto Aisén, Felipe Osorio, 45 24' 25,98' S - 72 ${ }^{\circ} 41^{\prime}$ 09” W. New for the Region. Southern extension of its distribution range.

The plants were found growing on the trunk of Nothofagus dombeyi (Mirb.) Oerst. This species 
is distinguished by its sporophytes with erect capsules and conspicuous differentiation between the apical and basal cells of the leaves. It has been reported from Argentina and Bolivia. In Chile, the species is distributed from the Province of Antofagasta to Osorno.

10. Kindbergia praelonga (Hedw.) Ochyra. (SGO 160486), Province of Aysén, Aysén Region: main square of Puerto Aysén Felipe Osorio, 45 24' $25,98^{\prime}$ S $-72^{\circ} 41^{\prime} 09^{\prime}$ W. New for the Region.

The plants were found forming dense patches with grasses of the genus Holcus. This species is common in urban parks. It is distinguishable by the branch leaves being acute, while the stem leaves are acuminate (MacFarland, 1994). $K$. praelonga is a common species in the Northern Hemisphere and has been reported from Tanzania, New Zealand, southern Australia and Tasmania in the Southern Hemisphere. It is also known from Mexico to southern Chile along the Andes, and Malvinas Islands (Matteri and Ochyra, 1989). In Chile, it has been reported between the Maule and Magallanes Regions (Müller, 2009).

11. Rhacocarpus purpurascens (Brid.) Paris. (SGO 160473), Province of Palena, Los Lagos Region: Parque Pumalín, Río Gonzalo, 100 meters north of the ranger's house, near the bay, Felipe Osorio, 22.02.2008, $42^{\circ} 35^{\prime} \mathrm{S}-72^{\circ} 35^{\prime} \mathrm{W}$. New for the Province.

The plants were found on rocks. Postrate habit, pinnate branching, fiddle-shaped leaves, and linear cells appearing to be densely and minutely papillose over the side walls (Crum, 1994). It is known from East Africa, Reunion Island, Madagascar, Indonesia, Australia, Tasmania, New Zealand, Mexico, Central America, the "West Indies" and South America (Robinson, 1975). In Chile, it has been cited in the Provinces of Valdivia, Llanquihue and Chiloé and in the Aysén and Magellan Regions, including the Juan Fernández archipelago (Müller, 2009).
12. Sphagnum capillifolium (Ehrh.) Hedw. (SGO 160470), Province of Aysén, Aysén Region: in peat 300 meters northwest of the Río Cuervo, Felipe Osorio, 02. 2008, 658497 E- 4991130 N. New for the Region. Southern extension of its distribution range.

This is an ombrotrophic species found in acidic environments. It forms dense carpets on wet outcrops and bogs. It has a characteristic pink-colored gametophyte, stem leaves with an entire apex and lageniform cells with a prominent neck. A description and illustration are available in Daniels and Eddy (1985), and another description is available in Andrus (2011). This species is widely distributed in North America, middle and northern Europe, Japan, Korea and the Russian Far East (Crum, 1984). In Chile, it has been recorded in the Los Ríos and Los Lagos Regions and in the Provinces of Valdivia/Ranco, Llanquihue and Chiloé.

13. Tayloria mirabilis (Cardot) Broth. (SGO 160469), Province of Coihaique, Aysén Region: Cerro Castillo, Nothogafus antarctica secondary forest biological material (fecal) from Guanaco, Pablo Bravo Monasterio, 26.02.2010, 727.942,059 E - 4.890.195,077 N. New for the Region.

The plants are usually growing on corpses and feces. Spore dispersal occurs through flies (Diptera) (Jofre et al., 2010). Distinctive features of the species that separate it from the related species T. dubyi Broth., T. magellanica (Brid.) Mitt. and T. stenophysata (Herzog) A.K. Kop. are its dentate or crenulate leaves, hypophysis paler than the rest of the capsule, and being inflated and white when ripe (Koponen, 1982). Müller (2009) established the presence of Tayloria mirabilis in the Araucanía Region (Provinces of Cautín and Malleco) and Magallanes Region (Provinces of Antartica Chilena, Magallanes, Tierra del Fuego and Última Esperanza).

\section{Corrected historical records}

14. Barbula austrogracilis Dus. (PC-FUSION14049), In Insula J. Fernandez, legit. Bertero, 
Barbula flagellaris Schimp., Tortula muralis var. australis, Montag. Prod. J. Fer. (label inside voucher: Rancagua 90, ad muros, Barbula unguiculata). This is believed to be the second record of the species for the Province of Cachapoal.

The species was first collected by Dusén in 1896 in Termas de Cauquenes (Province of Cachapoal) and described by him in 1906; it has never been recorded since that time. A specimen kept in Montagne's Herbarium in PC and erroneously identified as Barbula fragellaris (= Syntrichia flagellaris) from the Juan Fernandez Islands was examined. The specimen is intermixed with Syntrichia scabrella (Dusén) R.H. Zander plants and was gathered nearly 70 years before that collected by Dusén by Bertero, it is believed to come from the neighborhood of Rancagua based on interpretation of the collector's number (Rancagua 90) on a label inside the voucher. In this study, the voucher specimen's information written by Montagne (In Insula J. Fernandez) is considered to represent a transcription error. The presence of Syntrichia scabrella, which is a species restricted to continental Chile, with the specimen supports this assumption. A careful taxonomic study of $B$. austrogracilis Dusén could establish whether the taxon corresponds to a synonym of another species with a wider distribution. It is now known from two localities in central Chile, which were previously mentioned: Rancagua and Termas de Cauquenes. He (1998) and Müller (2009) erroneously reported B. austrogracilis from the Province of Colchagua due to recording an incorrect location for the type locality, Termas de Cauquenes, which is located in the Province of Cachapoal. Description (in Latin) and illustration in Dusén (1906).

\section{Additions based on the literature}

15. Chiloscyphus trigonifolius Steph. National record. Easter Island.

Tixier (1988) referred to one specimen collected by P. Cabalion on Easter Island as fol- lows: "Nord du cratère de Rano Kao, éboulis couverts de vigne plus ou moins sèche, limite supérieure de la bambusaie sur rochers, à $50 \mathrm{~cm}$ de la surface du sol, en mélange avec Lejeunea, Cabalion 18. Nous avons adopté le nom donné par STEPHANI à un taxon néo-calédonien. Le genre aurait besoin d'une monographie dans le Pacifique".

Grolle (2002) and Hässel de Menéndez and Rubies (2009) did not mention the species on this island or Tixier's article. Therefore, the report should be considered a national record to be added to the liverwort flora of Chile.

16. Lejeunea micholitzii Mizut. National record. Easter Island.

Tixier (1988) referred to 4 specimens collected by P. Cabalion in Easter Island as follows: "Cràtere du Rano Kao, éboulis au sol couvert de vignes et Melia azedarach, $60 \mathrm{~m}$ au-dessus du lac, Cabalion 1 - Idem, sur Melia azedarach, $2 \mathrm{~m}$ au-dessus du lac, Cabalion 10 - Idem, sur bois pourri, à $3 \mathrm{~m}$ de la surface du lac, Cabalion 30 - Idem, sur rochers, Cabalion 31. Espèce de l'Asie du Sud-Est et du Pacifique. Il faudrait revoir le genre Lejeunea; ce matériel est très proche de Lejeunea ecklonii Lindenb. ex Stephani, de l'Afrique tropicale".

Grolle (2002) and Hässel de Menéndez and Rubies (2009) did not mention the species for the island or Tixier's article. Therefore, the report should be considered a national record to be added to the liverwort flora of Chile.

17. Sematophyllum contiguum (Mitt.) Mitt. National record. Easter Island.

Tixier (1988) referred to 2 specimens collected by P. Cabalion on Easter Island as follows: "Éboulis rocheux sur le cratère de Rano Kao, sur rochers, $700 \mathrm{~m}$ au-dessus du lac, Cabalion 6 - Cratère de Rano Kao, en fôret sur rochers, $2 \mathrm{~m}$ au-dessus de l'eau, Cabalion 27. Espèce ubiquiste'. 
Ireland and Bellolio (2002) and Müller (2009) did not mention the species for the island or Tixier's article. Therefore, the report should be considered a national record to be added to the moss flora of Chile.

18. Syntrichia flagellaris (Schimp.) Zand. Reported here for the Province of Quillota (a) and the Libertador Bernardo O’Higgins Region (b).

Thériot (1917) cited two specimens gathered by Bertero in Quillota and Rancagua (the Valparaiso and Libertador Bernardo O'Higgins Regions, respectively). This endemic moss has been reported from the Provinces of Valparaíso, Santiago, Valdivia, Aysén and Magallanes. It has also been reported from the Juan Fernandez Islands. Its morphological characters were described by Cano and Gallego (2008). Further information is given in the original description by Schimper (1836) under the name of Barbula flagellaris and by Montagne (1850) under the name Tortula flagellaris. A detailed illustration is available in Schimper (1836).

\section{Acknowledgments}

We especially thank the Botanical Department of the Museo Nacional de Historia Natural (Chile) for access to facilities and for financial support (FAIP-MNHN and Biodiversity of Aysén Projects), the Cryptogamic Herbarium of Muséum National d'Histoire Naturelle (France) for providing facilities, the project Biodiversidad del Archipiélago de Chiloé (Asociación de Municipios Chiloé 2008) for financial support and the staff of the Grupo de Flora, led by Prof. Luis Faúndez, Laboratory of Plant Taxonomy, Faculty of Agronomy, Universidad de Chile. We also thank MO for the loan of specimens, Raleigh International for logistic support during the expedition to the Tamango Reserve and Pumalín Park for providing facilities. We especially thank Vanessa Morales for designing the map.

\title{
Resumen
}

\begin{abstract}
J. Cuvertino, V. Ardiles, F. Osorio y X. Romero.2012. Nuevos registros y adiciones a la flora de briófitas chilenas. Cien. Inv. Agr. 39(2): 245-254. El conocimiento briológico en Chile es escaso. Con el objetivo de realizar una contribución dirigida a incrementar el conocimiento de la distribución de las especies y estimular la realización de estudios briológicos y la conservación de estas plantas en el país, se presentan los resultados de diversas investigaciones florísticas. Se entregan 19 registros nacionales, regionales y provinciales para 17 especies de briófitas, obtenidos a través de la revisión de especímenes y sobre base bibliográfica. Seis de estos registros también corresponden a extensiones en el rango de distribución. Adicionalmente, la localidad tipo de un taxón (Barbula austrogracilis Dus.) es corregida y se establece un segundo registro para la especie.
\end{abstract}

Palabras clave: Briófitas, Chile, flora chilena.

\section{References}

Andrus, R.E. 2011. Bryophyte Flora of North America: Sphagnaceae, Sphagnum. Available online at:, http://www.efloras.org/florataxon.aspx?flora $\mathrm{id}=50$ andtaxon_id=240000095 (Website accessed: April 15, 2011).

Asakawa,Y., A. Ludwiczuk, F. Nagashima, M. Toyota, T. Hashimoto, M. Tori, Y. Fukuyama and L. Harinantenaina. 2009. Bryophytes: Bio- and 
Chemical Diversity, Bioactivity and Chemosystematics. Heterocycles 77:99-150.

Bednarek-Ochyra, H., J. Vana, R. Ochyra, and R. Lewis-Smith. 2000. The liverwort flora of Antarctica. Krakow: Polish Academy of Science, Institute of Botany.

Cano, M.J., and M.T. Gallego. 2008. The genus Tortula (Pottiaceae, Bryophyta) in South America. Botanical Journal of the Linnean Society 156 : 173-220.

Crum, H. 1984. Sphagnopsida, Sphagnaceae. New York: New York Botanical Garden. North American Flora Ser. II, Part 11, p. 1-180.

Crum, H. 1994. Rhacocarpaceae. In: Sharp, A.J., H. Crum, and P.M. Eckel (eds.), Memoirs of the New York Botanical Garden: New York. New York Botanical Garden. Moss Flora of Mexico 69: 667.

Daniels, R.E. and A. Eddy. 1985. Handbook of European Sphagna. Huntington: Institute of Terrestrial Ecology.

Dusén, P. 1906. Beiträge zur Bryologie der Magellansländer von Westpatagonien und Südchile. IV. Arkiv för Botanik utgivet av K. Svenska Vetenskaps-Akademien 6:1-40, Tafl. 1-12.

Grolle, R. 2002. The Hepaticae of the Easter Island (Chile). The Bryologist 105: 126-127.

Hässel de Menéndez, G.G. 1998. Avances en taxonomía de Hepatophyta y Anthocerothophyta Austrosudamericanas. Proceedings of the VI Congreso Latinoamericano de Botánica 1994. Monographs in Systematic Botany from the Missouri Botanical Garden 68: 87-100.

Hässel de Menéndez, G., and M. Rubies. 2009. Catalogue of the Marchantiophyta and Anthocerotophyta from Chile, Argentina and Uruguay. Nova Hedwigia 134: 1-672.

Hässel de Menéndez, G., and S. Solari. 1975. Bryophyta Hepaticopsida: Calobryales, Jungermanniales: Vetaformaceae, Balantiopsidaceae. In: Guarrera, S.A., Gamundi de Amos, I. and Rabinovich de Halperin, D. (eds.). Flora Criptogámica de Tierra del Fuego 15: 21-165. Buenos Aires: Consejo Nacional de Investigaciones Científicas y Técnicas de la Republica Argentina.
He, S. 1998. A checklist of the mosses of Chile. Journal of the Hattori Botanical Laboratory 85 :103189.

IGMCH. 2002. Listado de Nombres Geográficos Versión 1.0. 1 Compact Disc. IGMCH (Instituto Geográfico Militar de Chile, CL).

Ireland, R.R., and G. Bellolio. 2002. The Mosses of Easter Island. Tropical Bryology 21: 11-19.

IUCN. 2008. The 2000 IUCN World Red List of Bryophytes. IUCN (International Union for Conservation of Nature, Species Survival Commission Bryophyte Specialist Group). Available online at: http://www.artdata.slu.se/guest/SSCBryo/WorldBryo.htm (Website accessed: April 15, 2011).

Jofre, J., F. Massardo, R. Rozzi, B. Goffinet, P. Marino, R.A. Raguso and N.P. Navarro. 2010. Fenologia de la fase esporofitica de Tayloria dubyi (Splachnaceae) en las turberas de la Reserva de Biosfera Cabo de Hornos. Revista Chilena de Historia Natural 83: 195-206.

Koponen, A. 1982. The generic classification of the Splachnaceae. Beiheft zur Nova Hedwigia 71: 239-247.

Larraín, J., F. Herrera, J.M. Budke, and B. Goffinet. 2009. Phylogenetic affinities and conservation status of the Chilean endemic Costesia spongiosa (Gigaspermaceae). The Bryologist 112: 278-286.

Matteri, C.M. 1985. Catálogo de los musgos. In: Boelcke, O., D.M. Moore, and F.A. Roig. (eds.). Transecta botánica de la Patagonia austral. Buenos Aires: Consejo Nacional de Investigaciones Científicas y Técnicas, Punta Arenas: Instituto de la Patagonia, London: Royal Society. p. 265-298.

Matteri, C.M., and R. Ochyra. 1989. Notes on two southern South American species of Brachytheciaceae (Musci). Journal of the Hattori Botanical Laboratory 66: 321-330.

McFarland, K.D. 1994. Kindbergia. In: Sharp, A.J., H. Crum, and P.M. Eckel (eds.). Memoirs of the New York Botanical Garden: Moss Flora of Mexico 69: 943-945. New York: New York Botanical Garden.

Mitten, W. 1869. Musci austro-americani Enumeratio omnium Austro-americanorum auctori hu- 
cusque congitorum. Journal of the Linnean Society, Botany 12: 1-659.

Montagne, C. 1850. Flora chilena, plantes cellulaires. I. Musgos. In: Gay, C. (ed.). Historia física y política de Chile 7: 5-202). Paris, France.

Müller, F., and R. Pursell. 2003. The genus Fissidens (Musci, Fissidentaceae) in Chile. Journal of the Hattori Botanical Laboratory 93: 117-139.

Müller, F. 2009. An updated checklist of the mosses of Chile. Archive for Bryology 58: 1-124.

Putzke, J., and A.B. Pereira. 2001. The Antarctic Mosses with special reference to the South Shetland Island. Canoas, RS - Brasil: Editora da Ulbra. $196 \mathrm{pp}$.

Robinson, H. 1975. The mosses of Juan Fernandez Islands. Smithsonian Contributions to Botany 27: $1-88$.

Rozzi, R., J. Armesto, B. Goffinet, W.R. Buck, F. Massardo, J.Jr. Silander, M. Kalin-Arroyo, S. Russell, C. Anderson, L. Cavieres, and B. Callicott. 2008. Changing biodiversity conservation lenses: Insights from the Subantarctic non-vas- cular flora of southern South America. Frontiers in Ecology and the Environment 6: 131-137.

Schimper, W.P. 1836. Muscorum chilensium species novas descripsit. Annales des Sciences Naturelles, Botanique, sér. 2, 6:145-149.

Stech, M. and W. Frey. 2004. Molecular circumscriptions and relationships of the selected gondwanan species of Haplomitrium (Calobryales, Haplomitriopsida, Hepaticophytina). Studies in austral temperate rain forest bryophytes 24 . Nova Hedwigia 78: 57-70.

Thériot, I. 1917. Contribution a la flore bryologique du Chili. Revista Chilena de Historia Natural 21: 6-37.

Thériot, I. 1921. Contribution a la flore bryologique du Chili. Revista Chilena de Historia Natural 25: 289-312.

Tixier, P. 1988. Bryophytes de I'Île de Pâques. Cryptogamie, Bryologie et Lichénologie 9: 47-50.

Tropicos. 2011. Missouri Botanical Garden. Available online at: http://www.tropicos.org/Home. aspx (Website accessed: July 15, 2011). 